University of Nebraska - Lincoln

DigitalCommons@University of Nebraska - Lincoln

USDA National Wildlife Research Center - Staff Publications
U.S. Department of Agriculture: Animal and Plant Health Inspection Service

May 2001

Density of Prairie Skinks (Eumeces septentrionalis) in Old-field Habitats

William C. Pitt

Utah State University, Logan

Follow this and additional works at: https://digitalcommons.unl.edu/icwdm_usdanwrc

Part of the Environmental Sciences Commons

Pitt, William C., "Density of Prairie Skinks (Eumeces septentrionalis) in Old-field Habitats" (2001). USDA National Wildlife Research Center - Staff Publications. 513.

https://digitalcommons.unl.edu/icwdm_usdanwrc/513

This Article is brought to you for free and open access by the U.S. Department of Agriculture: Animal and Plant Health Inspection Service at DigitalCommons@University of Nebraska - Lincoln. It has been accepted for inclusion in USDA National Wildlife Research Center - Staff Publications by an authorized administrator of DigitalCommons@University of Nebraska - Lincoln. 


\title{
Density of Prairie Skinks (Eumeces septentrionalis) in Old-field Habitats
}

\author{
WILLIAM C. PITT \\ Utah State University, Ecology Center and Department of Fisheries and Wildlife Logan, 84322
}

\begin{abstract}
From 1996-1998 I estimated the density of prairie skinks (Eumeces septentrionalis) in old fields and evaluated the influence of habitat characteristics on density. I estimated prairie skink density from a trapping grid using a mark-recapture method in seven old fields. For each field I estimated arthropod density, percent plant cover and recorded field age and if the field had been burned in the last $5 \mathrm{y}$. Arthropod density was highly variable among years and fields. Percent plant cover did not explain this variation, as it varied little among fields and years. Prairie skink density ranged from 58-206 adults per ha among fields and was significantly correlated with field age, arthropod abundance and burn treatment. Because of the small number of replicated sampling units, however, I was unable to determine the independent effects of each factor. Prairie skink density increased with successional age but the mechanisms responsible for this pattern remain unclear.
\end{abstract}

\section{INTRODUCTION}

Predatory lizards are widespread in many terrestrial communities and can have dramatic influences on arthropod populations (Schoener and Toft, 1983; Pacala and Roughgarden, 1984; Spiller and Schoener, 1988, 1994). Little is known, however, about population sizes and the ecological factors that limit lizard populations in temperate regions (Diaz and Carrascal, 1991; Diaz, 1997; McLeod and Gates, 1998). Lizard populations are influenced by thermal conditions and habitat structure (e.g., woody debris) as well as predator and prey abundance (James, 1991; Diaz and Carrascal, 1991; Mushinsky, 1992; Seburn, 1993; Martin and Lopez, 1996; Diaz, 1997; Hecnar and M'Closkey, 1998; McLeod and Gates, 1998). Although predation is considered to be a major source of mortality for some lizard populations (Mclaughlin and Roughgarden, 1989; Wilson, 1991), many studies suggest that lizard populations may be limited by the abundance of prey (Diaz and Carrascal, 1991; Diaz, 1997; McLeod and Gates, 1998). The most important factors limiting lizard populations, therefore, continue to be debated and may differ across study sites (Diaz and Carrascal, 1991).

Northern prairie skinks (Eumeces septentrionalis) are small carnivorous lizards inhabiting tallgrass prairie habitats from Minnesota to Texas (Conant, 1975). Prairie skink diets in Minnesota are generalized and typically consist of Orthoptera $(27.3 \%$ by frequency of occurrence), Arachnida (29.5\%), Lepidoptera (10.1\%, mainly larvae), Coleoptera (9.4\%), Homoptera $(8.6 \%)$, Diptera $(4.3 \%)$, Hemiptera $(3.6 \%)$ and Hymenoptera $(2.9 \%)$ (Breckenridge, 1943). Prairie skinks are prey for birds, mammals, snakes and occasionally other prairie skinks (Breckenridge, 1943). Skinks (Eumeces spp.) are relatively long-lived (to 10 y) and have relatively low reproductive rates (Breckenridge, 1943; Snider and Bowler, 1992). In Minnesota prairie skinks reach sexual maturity at 21 mo and females lay 5-13 eggs annually in a single clutch (Breckenridge, 1943).

The objectives of this study were to determine density of northern prairie skinks, identify any trends in density with plant succession and identify any relationship between prairie

\footnotetext{
${ }^{1}$ Present address: USDA, Wildlife Services, National Wildlife Research Center, UMC 5295, Utah State University, Logan 84322. Telephone (435) 245-6091; FAX (435) 245-3156; e-mail: ww@cc.usu.edu
} 
skink and arthropod density. I estimated prairie skink density in old fields that differed in age and measured three important habitat characteristics in each field: arthropod density, vegetative cover and burn frequency. One of the following four hypotheses potentially explains the pattern of density. Hypothesis one, if prairie skinks are limited by the density of prey items, their numbers should be associated with arthropod density (Diaz and Carrascal, 1991; James, 1991; Hasegawa, 1994). Hypothesis two, if cool thermal conditions limit growth and reproductive rates of prairie skinks, prairie skink density should increase as total plant cover decreases (i.e., increase in solar radiation) (Seburn, 1993; McLeod and Gates, 1998). Prairie skink density would increase because ambient temperatures are usually well below optimal activity temperatures (>30 C, Goin et al., 1978) in northern climates and lizards rely heavily on solar radiation to increase body temperatures and maintain activity (Regal, 1978). Direct solar radiation reaching the soil surface decreases as plant cover increases because of the interception of radiation by leaves (Rauner, 1977; Gates, 1980). Hypothesis three, if prairie skinks are limited by the amount of woody debris, which serves as a refuge from predators and suboptimal thermal conditions, then burned fields which have less woody debris will have fewer prairie skinks (Mushinsky, 1992; Downes and Shine, 1998; Hecnar and M'Closkey, 1998). Alternatively, fields with greater plant cover may receive less solar radiation; therefore burned fields may contain more prairie skinks. Hypothesis four, if prairie skinks are limited by predation, they will be more abundant in fields with more total plant cover. Indications of previous predation attempts, as judged from tail breakage scars, should occur at high frequency in fields with lower plant cover (Vitt and Cooper, 1986; Wilson, 1991).

I tested these hypotheses by conducting a mark recapture study from 1996-1998 in seven old fields of varying successional age to determine density. I compared prairie skink density to arthropod density, successional age of fields, total plant cover and whether the field had been previously burned in the last $5 \mathrm{y}$.

\section{Methods}

Research was conducted in the successional old fields at Cedar Creek Natural History Area (CCNHA), located approximately $60 \mathrm{~km}$ north of Minneapolis in east-central Minnesota on a glacial outwash sandplain with nitrogen-poor soils (Tilman, 1987). I measured prairie skink density and habitat characteristics in seven old fields, abandoned from farming between 1937-1986 and now surrounded by forest. Two of the fields were burned once every $3 \mathrm{y}$ as part of a long-term burning experiment (Tester, 1989). Young fields $(<30 \mathrm{y}$ since abandonment) were dominated by annual forbs (e.g., Ambrosia artemisiifolia and Erigeron spp.) and perennial weedy grasses (e.g., Poa pratensis and Agropyron repens). Fields abandoned $>40$ y ago were dominated by prairie grasses (e.g., Schizachyrium scoparium and Panicum spp.), diverse perennial forbs and woody plants (e.g., Rosa arkansana and Rhus radicans). Grasshoppers (Orthoptera: Acrididae), a preferred prey, are the most abundant insects (Ritchie and Tilman, 1992, 1993). Birds (e.g., American kestrels, Falco sparverius), mammals (e.g., raccoons, Procyon lotor), snakes (e.g., western hognose snakes, Heterodon nasicus) are potential predators but are rare in these fields (Huntly and Inouye, 1987; Wovcha et al., 1995; Davis et al., 2000).

From 1996-1998 I estimated prairie skink densities, arthropod densities and percent cover of plant species in these seven old fields. Prairie skink density was estimated with a single trapping grid in each field placed from 1 July-30 August. Three of the fields were trapped all $3 \mathrm{y}$, although trapping grids were placed in new random locations each year. I placed the grids in random locations each year to reduce potential trapping biases associated with the placement of grids for any $1 \mathrm{y}$. Each grid $(30 \times 30 \mathrm{~m})$ consisted of thirty-six 20 -cm diam 
pitfall traps, placed $5 \mathrm{~m}$ apart and covered with a $30 \times 30 \mathrm{~cm}$ square piece of plywood. The top of the pitfall trap was $1 \mathrm{~cm}$ below ground level, thus the skinks moved easily underneath the plywood cover. Each pitfall was checked every 24-48 h. I recorded the mass, sex (when possible), length, age class and tail condition (e.g., complete, missing, regenerated) of each prairie skink. Tail condition and length were noted only during the last 2 y of the study. All prairie skinks older than 6 mo (i.e., older than young of the year) were uniquely marked by toe clipping and released at the point of capture. Prairie skinks less than $1 \mathrm{y}$ in age have a bright blue tail and are much smaller than adults (Breckenridge, 1943). Prairie skink density was estimated as the minimum number known alive, that is the total number of prairie skinks marked in the grid divided by the area of the trapping grid plus a 5 -m buffer $(0.16 \mathrm{ha})$. This method may overestimate actual density because the trapping grid may be sampling a much larger area by including prairie skinks using the edge of the grid (Schoener, 1994).

Most (90\% by frequency of occurrence) of the arthropods prairie skinks feed upon were collected in sweep nets, but pitfall traps were also used to collect ground dwelling arthropods (Breckenridge, 1943). Density of large (>5 mm in length) arthropods was estimated by a sweep collection during the last week of August each year. I randomly located six $5 \times$ 5 -m plots in each field and systematically swept each plot with a muslin net for three or four consecutive 1-min periods with 1-min rest between periods. When an insect was observed escaping from the plot, the individual was collected outside of the plot or a note was made of its identity, if possible. After each sweep period the net contents were emptied into a plastic bag and stored at $15 \mathrm{C}$. After all plots were sampled, the samples were frozen at $-15 \mathrm{C}$, sorted and identified. All grasshoppers and common arthropods were sorted to species, whereas rare $(<3$ per sample) arthropods were sorted to family. By conducting at least three consecutive sweeps per plot, I estimated density using a catch-effort technique (Southwood, 1978). Using linear regression I estimated the x-intercept of a regression of number caught in the current sweep (dependent variable) vs. cumulative catch over the current and previous sweeps (independent variable). The x-intercept of the regression was an estimate of the density within the plots. Every 24-48 h I counted, identified and then released all arthropods collected in pitfalls. The relative abundance of ground dwelling arthropods in each field was quantified as the mean number collected in pitfalls per trap day.

I estimated the percent cover $( \pm 2 \%)$ of plant species in six $0.5-\mathrm{m}^{2}$ sampling quadrats randomly located adjacent $(<20 \mathrm{~m})$ to each trapping grid. I recorded all plant species and recorded visual percent cover using a $0.5-\mathrm{m}^{2}$ frame divided into $10 \times 10 \mathrm{~cm}$ sections (Inouye et al., 1987). I counted the total number of sections (or parts of sections) that covered each species. Field age was determined from official records at CCNHA. These records are based on field research since 1929, aerial photographs and land acquisition dates since CCNHA was established in 1940 (Hodson, 1985; Tilman, 1987).

I used a weighted multiple regression to test for a relationship between average prairie skink density, average arthropod density and field age (years since abandonment). The regression was weighted based on the number of years each field was sampled. I used an unpaired $t$-test to compare prairie skink density between burned and unburned fields. Percent plant cover was not included in the analysis because it varied little among fields and thus, would not explain variation of prairie skinks across fields.

\section{RESULTS}

I captured 249 adult prairie skinks (881 total captures) and 115 hatchlings on 13 trapping grids in the seven old fields. Prairie skink density varied among fields from 9-38 individuals 
TABLE 1.-Field age (years since abandonment), number of years sampled, mean skink density, mean arthropod density, mean total plant cover and mean plant cover by functional group of seven old fields

\begin{tabular}{|c|c|c|c|c|c|c|c|c|c|}
\hline \multirow[b]{3}{*}{ Field age } & \multirow{3}{*}{$\begin{array}{l}\text { Number } \\
\text { of years } \\
\text { sampled }\end{array}$} & \multirow{3}{*}{$\begin{array}{c}\text { Prairie } \\
\text { skink } \\
\text { density } \\
\text { (no./ha) }\end{array}$} & \multirow{3}{*}{$\begin{array}{c}\text { Arthropod } \\
\text { density } \\
\left(\text { no. } / \mathrm{m}^{2}\right)\end{array}$} & \multirow[b]{3}{*}{ Burned } & \multicolumn{5}{|c|}{ Percent cover } \\
\hline & & & & & \multirow[b]{2}{*}{ Total plant } & \multirow[b]{2}{*}{ Shrub } & \multirow[b]{2}{*}{ Forb } & \multicolumn{2}{|c|}{ Grass } \\
\hline & & & & & & & & $\mathrm{C} 4$ & C3 \\
\hline 60 & 2 & 231 & 1.8 & Yes & 60 & 9 & 10 & 31 & 10 \\
\hline 53 & 2 & 188 & 1.1 & Yes & 58 & 11 & 14 & 25 & 8 \\
\hline 42 & 2 & 125 & 0.7 & No & 62 & 10 & 19 & 23 & 10 \\
\hline 41 & 1 & 125 & 1.6 & No & 61 & 2 & 10 & 20 & 29 \\
\hline 40 & 1 & 150 & 2.2 & No & 63 & $<1$ & 14 & 29 & 19 \\
\hline 30 & 2 & 125 & 1.5 & No & 63 & $<1$ & 16 & 16 & 31 \\
\hline 12 & 3 & 63 & 0.4 & No & 41 & 0 & 17 & 0 & 24 \\
\hline
\end{tabular}

per trapping grid (approximately 58-238 per ha). For adult females average snout vent length (SVL) was $57.3 \pm 1.2 \mathrm{~mm}$ and average mass was $4.6 \pm 0.5 \mathrm{~g}(\mathrm{n}=33)$. For adult males average SVL was $59.2 \pm 1.5 \mathrm{~mm}$ and average mass was $4.9 \pm 0.5 \mathrm{~g}(\mathrm{n}=36)$. SVL of hatchlings averaged $28.7 \pm 2.8 \mathrm{~mm}(\mathrm{n}=26)$. Only $7.6 \%$ of prairie skinks $(\mathrm{n}=108)$ had partially missing or regenerated tails.

Fields differed in insect density, plant species composition and total percent plant cover, which reflected field age and condition upon abandonment. Arthropod density varied widely among years, from $2.9 \mathrm{~m}^{-2}$ in 1996 to $0.3 \mathrm{~m}^{-2}$ in 1998 and among fields from $0.4-2.2$ $\mathrm{m}^{-2}$ (Table 1). Grasshoppers (primarily Acrididae and Tettigoniidae) were the most abundant arthropod, accounting for $>68 \%$ of individuals and $95 \%$ of the arthropod biomass collected in sweep nets. I collected twice as many field crickets (Gryllus spp.) in pitfall traps as all other arthropods combined. Total plant cover varied little among fields (41-63\%) and varied little among years within fields.

Prairie skink density was positively correlated with field age $(t=7.01,6 \mathrm{df}, \mathrm{P}<0.001$; Fig. 1). Intermediate aged fields (30-45 y) varied greatly in arthropod density, but did not differ in total plant cover. Prairie skink density was positively correlated with arthropod density $(t=2.60,6 \mathrm{df}, \mathrm{P}=0.048$; Fig. 2). I found $77 \%$ higher prairie skink densities in fields that had been burned $\left(188 \mathrm{ha}^{-1}\right)$ than in fields that had not been burned (106 ha$t=-3.40,5 \mathrm{df}, \mathrm{P}=0.019)$.

\section{DisCUSSION}

Density of prairie skinks was significantly correlated with field age and arthropod density, but not correlated with total vegetative cover. Prairie skinks were more abundant in burned fields, but burned fields were also the oldest. High arthropod density is the most likely factor explaining the high prairie skink density in old fields ( $>50 \mathrm{y}$, hypothesis one). The large variation in arthropod densities among years reduced the strength of this correlation. Prairie skink populations, with low reproductive rates, could not track highly variable arthropod densities. Thus, prairie skink populations were not as strongly correlated with average arthropod density as prairie skink populations were with field age.

Lizard population densities are often highest in warm climates (Seburn, 1993; McLeod and Gates, 1998). Thermal conditions in these Minnesota old fields, which are at the edge of prairie skinks' geographical range, may limit their density (hypothesis two). However, total plant cover, one possible indicator of thermal conditions, varied little among fields (Table 1). Other studies that have shown a significant influence of total plant cover on 




Field age (years since abandondment)

FIG. 1.-Estimated density of adult prairie skinks (Eumeces septentrionalis) in fields of different ages

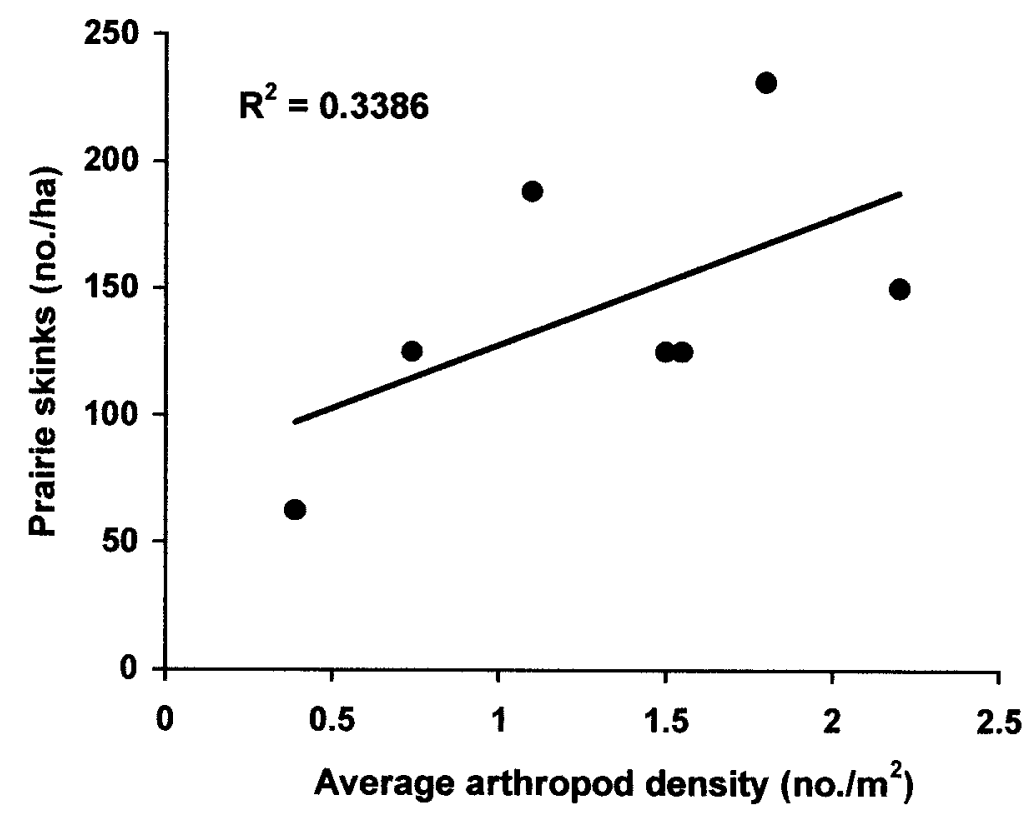

FIG. 2.-Estimated density of adult prairie skinks (Eumeces septentrionalis) and mean arthropod density 
prairie skink populations were comparing populations in sites with and without trees (Seburn, 1993; McLeod and Gates, 1998) or comparing lizard populations across regional scales (Diaz and Carrascal, 1991).

Mushinsky (1992) found that skink (Eumeces fasciatus) populations in Florida were higher in sites protected from burning, likely the result of greater coarse woody debris, leaf litter and tree canopy at unburned sites. The effect of litter and plant cover may be different in northern areas where the climate is much cooler (hypothesis three). In my study burned sites had higher skink densities than unburned sites, similar to the finding of McLeod and Gates (1998) in Maryland. Although trees and large woody debris are extremely rare in the fields at CCNHA (Inouye, 1994), shrubs and plant litter may have a similar effects on populations of skinks. Nevertheless, this result would be consistent with the hypothesis that, at the northern edge of its range prairie skinks respond to warm conditions created by open habitat structure. In this study only two of the fields were burned and these were also the two oldest fields. Therefore, it was difficult to separate the influence of burning and field age on prairie skink densities.

Although predation can limit lizard populations (hypothesis four; Martin and Lopez, 1996), the apparent paucity of avian and mammalian predators at CCNHA precluded any useful comparison of predators between fields (Huntly and Inouye, 1987; Davis et al., 2000). The low frequency $(7.6 \%)$ of missing or regenerating tails potentially indicates the low influence of predators at CCNHA relative to other sites (Vitt and Cooper, 1986; Wilson, 1991). Vitt and Cooper (1986) found more than $40 \%$ of skinks (Eumeces spp.) were missing tails in the southeastern United States. Thus, the lack of a correlation between prairie skink densities and factors that may influence predation (e.g., vegetative cover) is not surprising.

The relationship between arthropod density and prairie skink density $\left(r^{2}=0.38\right)$ and the strong relationship between field age and prairie skink density $\left(r^{2}=0.91\right)$ suggests an additional hypothesis to prey limitation. Prairie skink populations may be slow to colonize and expand populations in successional habitats because of their slow population growth. If an adult pair of prairie skinks colonized a recently abandoned field, the pair and their offspring reproduce at their maximum rate (six offspring annually) and no prairie skinks die, it would take $10 \mathrm{y}$ for prairie skinks to exceed the densities I observed in a 10-ha field. However, it is unlikely that prairie skink populations realize these growth rates (i.e., $\mathrm{r}_{\max }=$ 0.54 , calculated from the above assumptions); thus, it could realistically take many more years for prairie skinks to attain the highest densities found in this study. The colonization rate of skinks in recently abandoned fields is unknown. Prairie skinks, as well as other lizards, are slow to respond to succession if scattered patches lack dispersal corridors and reproductive rates are low. Thus, prairie skinks in younger fields would not have reached saturation densities. However, the influence of possible colonization limitation of prairie skink populations needs to be investigated further and would be important in prairie restoration efforts

Acknowledgments.-My sincere gratitude is extended to the National Science Foundation (DEB9411972) and the Ecology Center, Utah State University, for providing me with financial support. I am indebted to those that assisted me with my field work S. Tonkin, L. Sheps, A. Loomis, K. Hollingshead, A. Guss, P. VanZandt and K. Yetter. I also would like to thank R. Powell, M. Ritchie, G. Belovsky, T. Evans, R. Mason, F. Provenza, K. Wenning and an anonymous reviewer who provided editorial suggestions. This paper is dedicated to W. J. Breckenridge for his research on prairie skinks in Minnesota.

\section{Literature Cited}

BreckenRIDGe, W. J. 1943. The life history of the black-banded skink Eumeces septentrionalis septentrionalis (Baird). Am. Midl. Nat., 29:591-606. 
CONANT, R. 1975. Field guide to reptiles and amphibians of eastern and central North America, 2nd ed. Houghton Mifflin Co., Boston, Mass. 354 p.

Davis, M. A., D. W. Peterson, P. B. Reich, M. Crozier, T. Query, E. Mitchell and J. Huntington. 2000. Restoring savanna using fire: impact on breeding bird community. Restoration Ecol., 8: $30-40$.

DIAZ, J. A. 1997. Ecological correlates of the thermal quality of an ectotherm's habitat: a comparison between two temperate lizard population. Functional Ecol., 11:79-89.

— AND L. M. CARRASCAL. 1991. Regional distribution of a Mediterranean lizard: influence of habitat cues and prey abundance. J. Biogeogr., 18:291-297.

DownEs, S. AND R. SHINE. 1998. Heat, safety or solitude? Using habitat selection experiments to identify lizard's priorities. Anim. Behav., 55:1387-1396.

Gates, D. M. 1980. Biophysical ecology. Springer-Verlag, New York. 611 p.

GoIN, C. J., O. B. GoIN AND G. R. ZUG. 1978. Introduction to herpetology, 3rd ed. W. H. Freeman and Company, New York. 378 p.

HASEgAWA, M. 1994. Demography, social structure and sexual dimorphism of the lizard Eumeces okadae. Physiol. Ecol. Japan, 29:248-263.

HeCNAR, S. J. AND R. T. M'ClOSKEY. 1998. Effects of human disturbance on five-lined skink, Eumeces fasciatues, abundance and distribution. Biol. Conserv., 85:213-222.

Hodson, A. C. 1985. History of the Cedar Creek Natural History Area. University of Minnesota Field Biology Program, Occasional Papers Number 2. Minneapolis. 132 p.

HuntLY, N. AND R. S. INOuYE. 1987. Small mammal populations of an old-field chronosequence: succesional patterns and associations with vegetation. J. Mammal, 68:739-745.

INOUYE, R. S. 1994. Old-field succession on a Minnesota sand plain: effects of deer and other factors on invasion by trees. Bull. Torrey Bot. Club, 121:266-276.

JAMES, C. D. 1991. Population dynamics, demography, and life history of sympatric scincid lizards (Ctenotus) in central Australia. Herpetologica, 47:194-210.

Martin, J. AND P. Lopez. 1996. Avian predation on a large lizard (Lacerta lepida) found at low population densities in Mediterranean habitats: an analysis of bird diets. Copeia, 1996:722-726.

Mclaughlin, J. F. ANd J. Roughgarden. 1989. Avian predation on Anolis lizards in the Northeastern Caribbean: an inter-island contrast. Ecology, 70:617-628.

MCLEOD, R. F. AND J. E. GATES. 1998. Response of herpetofaunal communities to forest cutting and burning at Chesapeake Farms, Maryland. Am. Midl. Nat., 139:164-177.

Mushinsky, H. R. 1992. Natural history and abundance of southeastern five-lined skinks, Eumeces inexpectatus, on a periodically burned sandhill in Florida. Herpetologica, 48:307-312.

Pacala, S. And J. Roughgarden. 1984. Control of arthropod abundance by Anolis lizards on St. Eustatius (Neth. Antilles). Oecologia, 64:160-162.

Rauner, Y. L. 1977. Heat balance of the plant cover. Amerind Publ. Co., New Delhi, India. 219 p.

REGAL, P. J. 1978. Behavioral differences between reptiles and mammals: an analysis of activity and mental capabilities, p. 183-202. In: N. Greenberg and P. D. MacLean (eds.). Behavior and neurology of lizards. Natl. Inst. Mental Health, Rockville, Maryland.

Ritchie, M. E. AND D. Tilman. 1992. Interspecific competition among grasshoppers and their effect on plant abundance in experimental fields. Oecologia, 89:524-532.

1993. Predictions of species interactions from consumer-resource theory: experimental tests with grasshopper and plants. Oecologia, 94:516-527.

SchoenER, T. W. 1994. Temporal variability in lizard numbers: what is the appropriate kind of study population? Am. Nat., 144:868-872.

— AND C. TOFT. 1983. Spider populations: extraordinarily high densities on islands without top predators. Science, 219:1353-1355.

SEburn, C. N. L. 1993. Spatial distribution and microhabitat use in the five-lined skink (Eumeces fasciatus). Can. J. Zool., 71:445-450.

SNIDER, A. T. AND J. K. BowLer. 1992. Longevity of reptiles and amphibians in North America collections, Second Edition. Society for the Study of Amphibians and Reptiles, Milwaukee, Wisc. 44 p. 
Southwood, T. R. E. 1978. Ecological methods: with particular reference to the study of insect communities. Chapman Hall, New York. 391 p.

Spiller, D. A. And T. W. Schoener. 1988. An experimental study of the effect of lizards on web-spider community. Ecol. Monogr, 58:57-77.

1994. Effects of top and intermediate predators in a terrestrial food web. Ecology, 75:182-196.

Tester, J. R. 1989. Effects of fire frequency on oak savannah in east-central Minnesota. Bull. Torrey Bot. Club, 116:134-144.

Tilman, D. 1987. Secondary succession and the pattern of plant dominance along experimental nitrogen gradients. Ecol. Monogr., 57:189-214.

VitT, L. J. AND W. E. CoOper. 1986. Tail loss, tail color, and predator escape in Eumeces (Lacertilia: Scincidae): age-specific differences in costs and benefits. Can. J. Zool., 64:583-592.

WiLson, B. S. 1991. Latitudinal variation in activity season mortality rates if the lizard Uta stansburiana. Ecol. Monogr., 61:393-414.

Wovcha, D. S., B. C. Delaney and G. E. Nordquist. 1995. Minnesota's St. Croix River Valley and Anoka Sandplain: A guide to native habitats. Univ. Minn. Press, Minneapolis, Minn. 234 p.

Submitted 18 OCtOBER 1999

ACCEPTED 3 JANUARY 2001 